\title{
Iwona Franczak
}

Uniwersytet Ekonomiczny w Katowicach

e-mail: iwona.franczak@ue.katowice.pl

ORCID: 0000-0002-4936-5225

\section{MECHANIZM PODZIELONEJ PLATNOŚCI W PODATKU OD TOWARÓW I USŁUG A POLITYKA RACHUNKOWOŚCI JEDNOSTEK SAMORZĄDU TERYTORIALNEGO}

DOI: $10.15611 / \mathrm{pn} .2020 .11 .01$

JEL Classification: M41, H20, H72

(C)2020 Iwona Franczak

Praca opublikowana na licencji Creative Commons Uznanie autorstwa-Na tych samych warunkach 4.0 Międzynarodowe (CC BY-SA 4.0). Skrócona treść licencji na https://creativecommons.org/licenses/by-sa/4.0/deed.pl

Cytuj jako: Franczak, I. (2020). Mechanizm podzielonej płatności w podatku od towarów i usług a polityka rachunkowości jednostek samorządu terytorialnego. Prace Naukowe Uniwersytetu Ekonomicznego we Wroctawiu, 64(11).

Streszczenie: Mechanizm podzielonej płatności (split payment) został wprowadzony głównie $\mathrm{w}$ celu przeciwdziałania nadużyciom i oszustwom podatkowym w podatku od towarów i usług. W związku z wprowadzeniem nowych przepisów regulacja ta odnosi się również do jednostek samorządu terytorialnego, które są podatnikiem VAT. Celem artykułu jest przedstawienie technicznego ujęcia w polityce rachunkowości mechanizmu podzielonej płatności oraz konsekwencji przyjęcia przez jednostki samorządu terytorialnego poszczególnych rozwiązań w prowadzeniu jednego lub wielu rachunków VAT. Zastosowane metody badawcze to analiza aktów prawnych, przegląd literatury oraz wnioskowanie. W wyniku przeprowadzonych badań stwierdzono, że istnieje problem powiązania rachunków VAT z określonym rachunkiem rozliczeniowym i ścisłej kontroli widniejących na nim środków w transakcjach kupna i sprzedaży dokonywanych przez jednostki organizacyjne jednostek samorządu terytorialnego.

Słowa kluczowe: polityka rachunkowości, samorząd terytorialny, mechanizm podzielonej płatności.

\section{Wstęp}

System rachunkowości jednostek samorządu terytorialnego gromadzi, rejestruje oraz przetwarza informacje odnoszące się do każdego procesu czy zdarzenia mającego wpływ na sytuację majątkową i finansową tych jednostek. Polskie prawo 
bilansowe obliguje jednostki samorządu terytorialnego do posiadania dokumentu, który porządkuje przyjęte i stosowane przez nie zasady rachunkowości. Opracowanie, przyjęcie oraz stosowanie polityki (zasad) rachunkowości ma na celu rzetelne i jasne przedstawienie sytuacji majątkowej i finansowej, a także zaprezentowanie rzetelnego i wiernego obrazu jednostek szerokiemu gronu odbiorców (Ustawa z dnia 29 września 1994 r...., art. 4).

Przepisy ustawy z dnia 11 marca 2004 r. o podatku od towarów i usług (Dz. U. z 2020 r. poz. 106) normują kwestie mechanizmu podzielonej płatności w podatku od towarów i usług (split payment). Rozwiązanie to zostało wprowadzone przez Ministerstwo Finansów w celu zapewnienia stabilności wpływów z tego podatku, a także przeciwdziałania nadużyciom i oszustwom podatkowym z tytułu VAT (Prokop, 2018). Konsekwencją zastosowania mechanizmu podzielonej płatności przez podatników VAT są operacje pieniężne na bankowych rachunkach VAT.

Rachunkowość w sektorze publicznym ma swoiste uwarunkowania wynikające z samej specyfiki sektora publicznego. W celu uzyskania prawidłowo funkcjonującego systemu rachunkowości należy przy tworzeniu polityki rachunkowości dokonać analizy zachodzących w jednostce zdarzeń gospodarczych, a także na podstawie tej analizy wprowadzić odpowiednie zasady rachunkowości. Jednostki sprawozdawcze powinny wybrać takie zasady rachunkowości, które umożliwią rzetelnie i jasno odzwierciedlić prowadzoną działalność w księgach rachunkowych. Powstaje wówczas możliwość elastycznego dostosowywania się do nieograniczonej rodzajowo czy też jakościowo liczby zdarzeń. Sposób ewidencjonowania operacji z uwzględnieniem mechanizmu podzielonej płatności powinien być zatem uwzględniony w zaktualizowanej polityce rachunkowości jednostek samorządu terytorialnego.

Celem artykułu jest przedstawienie technicznego ujęcia w polityce rachunkowości mechanizmu podzielonej płatności oraz konsekwencji przyjęcia przez jednostki samorządu terytorialnego poszczególnych rozwiązań w prowadzeniu jednego lub wielu rachunków VAT. Zastosowane metody badawcze to analiza aktów prawnych, przegląd literatury oraz wnioskowanie.

\section{Polityka rachunkowości w jednostkach samorządu terytorialnego}

Zasady (politykę) rachunkowości rozumie się jako wybrane i stosowane przez jednostkę rozwiązania dopuszczone ustawą, w tym także określone w Międzynarodowych Standardach Rachunkowości, zapewniające wymaganą jakość sprawozdań finansowych (Ustawa o rachunkowości, art. 3 ust. 1 pkt 11). Przyjęta grupa rozwiązań ustawowych obejmuje przepisy, które zezwalają na wybór przez jednostkę określonych rozwiązań w zakresie sporządzania sprawozdań finansowych. Wyznaczają one ramy prawne własnej polityki rachunkowości konkretnej jednostki sprawozdawczej (Sawicki, 1996, s. 23). E. Walińska (2016, s. 196) zaznacza jednak, że bez względu na to, czy definiując pojęcie polityki rachunkowości, używa się określenia „,zasto- 
sowanie zasad", nie należy utożsamiać jej z wszystkimi zasadami rachunkowości, ponieważ polega ona na wyborze takich tylko zasad (jeśli wybór taki jest możliwy), które pozwolą lepiej odzwierciedlać w systemie rachunkowości rzeczywistość gospodarczą jednostki.

Jak zauważa się w literaturze, opracowanie prawidłowej oraz odpowiedniej dla określonego podmiotu polityki rachunkowości jest zadaniem złożonym, a także takim, które wymaga starannego przygotowania, decyduje ona bowiem o wiarygodności i porównywalności sprawozdań finansowych jednostek sprawozdawczych (Lander, 2003, s. 29-30).

Przyjęte zasady rachunkowości powinny być bieżąco aktualizowane. W celu rzetelnego i jasnego przedstawienia sytuacji jednostka może, ze skutkiem od pierwszego dnia roku obrotowego, bez względu na datę podjęcia decyzji, zmienić dotychczas stosowane rozwiązania na inne, przewidziane ustawą o rachunkowości. Do przesłanek zmian polityki rachunkowości należy zaliczyć m.in. (Gos i Hońko, 2011, s. 127-144):

1) zmiany regulacji prawnych,

2) dostosowanie regulacji wewnętrznych do zaleceń biegłych rewidentów i organów kontrolnych,

3) chęć wykorzystania uproszczeń wynikających z regulacji prawnych.

Zmiana dotychczas stosowanych rozwiązań wymaga również określenia $\mathrm{w}$ informacji dodatkowej wpływu tych zmian na sprawozdania finansowe (Ustawa o rachunkowości, art. 8 ust. 2). W takim przypadku należy w sprawozdaniu finansowym jednostki za rok obrotowy, w którym zmiany te nastąpiły, podać przyczyny tych zmian, określić liczbowo ich wpływ na wynik finansowy oraz zapewnić porównywalność danych sprawozdania finansowego dotyczących roku poprzedzającego rok obrotowy, w którym dokonano zmian (Zuchewicz, 2011, s. 337-350).

Polityka rachunkowości jest obligatoryjnym elementem regulacji wewnętrznych jednostek samorządu terytorialnego. Jej zapisy muszą być zgodne z regulacjami prawnymi i dostosowane do specyfiki działalności jednostki, tak by pozwoliły jak najrzetelniej przedstawić ich sytuację w sprawozdawczości. Jednocześnie zauważyć należy, że jednostki samorządu terytorialnego podlegają szczególnym zasadom rachunkowości w zakresie wyceny, ewidencji i sprawozdawczości, które to bezpośrednio wpływają na obraz sytuacji majątkowej oraz finansowej tych podmiotów. Polityka rachunkowości powinna być traktowana jako obligatoryjny zbiór wewnętrznych regulacji stosowanych $\mathrm{w}$ jednostce, na bieżąco aktualizowanych $\mathrm{w}$ efekcie zachodzących zmian wewnętrznych i zewnętrznych, takich jak np. zmiana regulacji prawnych (Adamek-Hyska, 2018).

Polityka rachunkowości przygotowywana jest oddzielnie dla każdego podmiotu, co wynika ze specyfiki jednostek sprawozdawczych i ich indywidualnych potrzeb. Jednostki samorządu terytorialnego przyjęte zasady (politykę) rachunkowości muszą dostosować zarówno do nadrzędnych zasad prawa bilansowego, jak i do zasad budżetowych. Odmienne uregulowanie norm rachunkowości budżetowej wynika 
ze szczególnych cech jednostek samorządu terytorialnego. Wymienione w ustawie o finansach publicznych podmioty nie są jednorodne pod względem swojego charakteru, funkcji czy zadań. Większość z nich ma osobowość prawną oraz autonomię $\mathrm{w}$ zakresie prowadzonej gospodarki finansowej. Inne z kolei nie mają osobowości prawnej, są tylko wyodrębnione organizacyjnie. Jednostki budżetowe i samorządowe zakłady budżetowe to jedne z podstawowych form organizacyjnych jednostek samorządu terytorialnego, które stosują zasady gospodarki finansowej zawarte w ustawie o finansach publicznych (Rechul i Witowska, 2014).

Przedmiotem rachunkowości jednostek sfery budżetowej są (Giedroyć i Hellich, 2018):

- zasoby majątkowe i źródła ich finansowania,

- procesy wynikające z zakresu finansów publicznych i ich rezultaty oraz wynik finansowy (wykonania budżetu),

- wynik finansowy (zysk lub strata, deficyt budżetowy lub nadwyżka).

W związku z powyższym sprawozdania finansowe i budżetowe powinny informować - zarówno odbiorców zewnętrznych, jak i kierownictwo jednostki samorządu terytorialnego - o jej sytuacji majątkowej i finansowej, wyniku finansowym i obciążeniach podatkowych (Giedroyć i Hellich, 2018).

Od 1 stycznia 2017 r. wszystkie jednostki samorządu terytorialnego w Polsce musiały dokonać tzw. centralizacji dla potrzeb podatku od towarów i usług. Oznaczało to scalenie rozliczeń w podatku od towarów i usług w taki sposób, aby w jednej zbiorczej deklaracji VAT ujmowane były zarówno czynności samej jednostki samorządu terytorialnego, jak i czynności poszczególnych jednostek organizacyjnych. Pojęciem ,jednostka organizacyjna” zostały objęte jednostki budżetowe oraz zakłady budżetowe oraz odpowiednio (w zależności od rodzaju jednostki organizacyjnej): urząd gminy, starostwo powiatowe, urząd marszałkowski. Jednostkami organizacyjnymi nie są tworzone przez samorząd terytorialny jednostki organizacyjne mające osobowość prawną, które są powoływane na podstawie przepisów odrębnych ustaw, np. spółki komunalne. One centralizacji nie podlegają (Bartosiewicz, 2018).

\section{Zasady działania mechanizmu podzielonej płatności w podatku od towarów i usług}

Mechanizm podzielonej płatności to rozwiązanie dotyczące sposobu dokonywania płatności poprzez wykorzystanie rachunku VAT dla posiadaczy rachunków rozliczeniowych prowadzonych przez banki albo imiennych rachunków w SKOK z tytułu należności udokumentowanych wystawioną fakturą z wykazaną kwotą VAT ( $\mathrm{Me}$ chanizm podzielonej płatności, 2019). Ustawodawca, wprowadzając mechanizm podzielonej płatności, nie zdefiniował specjalnych regulacji dla jednostek samorządu terytorialnego, co implikuje, że do grupy podatników będących jednostkami samorządu terytorialnego zastosowanie będą mieć również ogólne zasady stosowania mechanizmu podzielonej płatności (Niemiec, 2018). 
Mechanizm podzielonej płatności znajduje zastosowanie tylko w odniesieniu do transakcji wykonywanych na rzecz innych podatników VAT. Nie ma wpływu na transakcje, których stroną są nabywcy finalni niebędący podatnikami. Od 1 listopada 2019 r. płatność za nabycie towarów lub usług wymienionych w załączniku nr 15 do ustawy o podatku od towarów i usług, udokumentowana fakturą o kwocie brutto wyższej niż 15000 zł, musi być dokonana przez nabywcę za pomocą komunikatu przelewu (Ustawa o podatku od towarów i usług, art. 108a ust. 1a i 3). Równolegle nadal funkcjonuje wprowadzony ustawą z dnia 15 grudnia 2017 r. o zmianie ustawy o podatku od towarów i usług oraz niektórych innych ustaw dobrowolny mechanizm podzielonej płatności obejmujący pozostałe towary i usługi, a także towary i usługi wymienione w załączniku nr 15, jeżeli na fakturze dokumentującej ich nabycie występuje kwota nieprzekraczająca 15000 zł (Mechanizm podzielonej płatności, 2019).

Konstrukcja mechanizmu podzielnej płatności polega na podzieleniu przez nabywcę kwoty należnej dostawcy towarów albo usługodawcy na dwie części: kwotę stanowiącą wynagrodzenie netto oraz część odpowiadającą kwocie podatku od towarów i usług (rys. 1). Część odpowiadająca wartości podatku od towarów i usług zostaje wpłacona na specjalne, wyodrębnione konto nabywcy, określone jako rachunek VAT. Natomiast zapłata całości albo części kwoty odpowiadającej wartości sprzedaży netto, która wynika z otrzymanej faktury, dokonywana jest na rachunek

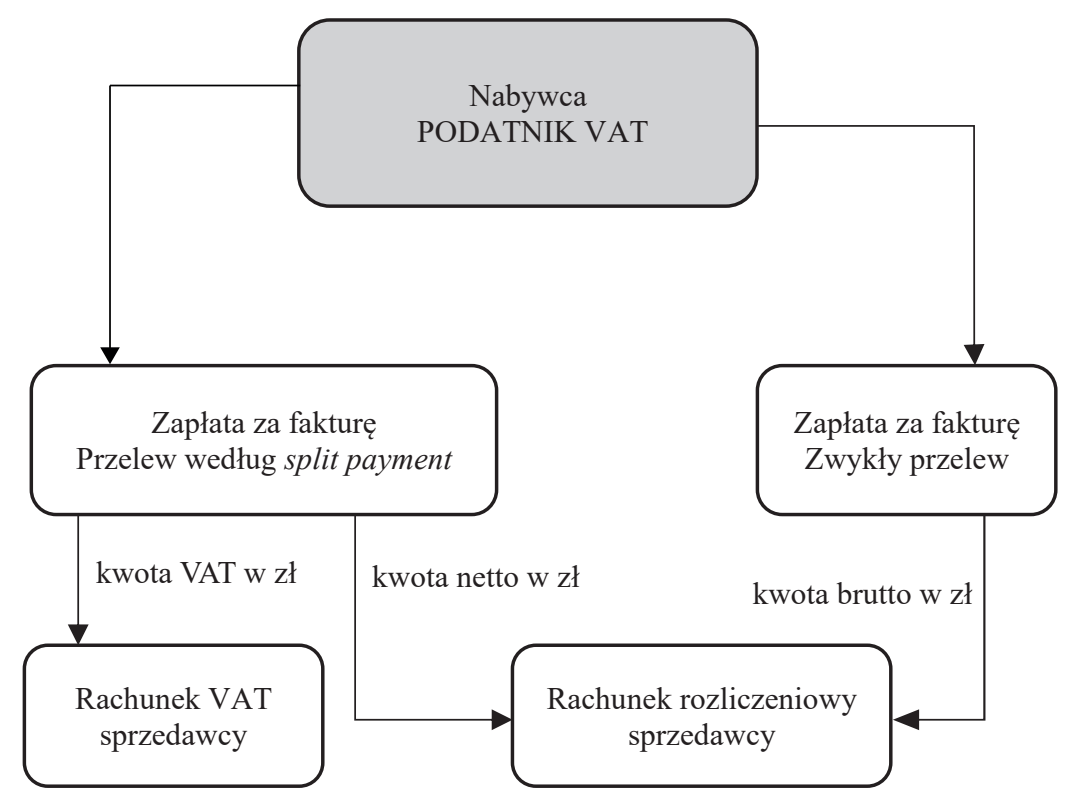

Rys. 1. Schemat mechanizmu split payment

Źródło: opracowanie własne na podstawie (Ustawa o podatku od towarów i usług, art 108a). 
bankowy lub na rachunek w spółdzielczej kasie oszczędnościowo-kredytowej, dla których jest prowadzony rachunek VAT albo jest rozliczana w inny sposób (Ustawa z dnia 11 marca 2004 r...., art. 108a ust. 2 pkt 1).

Mechanizm podzielonej płatności polega zatem na zautomatyzowanym podziale kwoty płatności brutto, który dokonywany jest na poziomie banku odbiorcy przelewu już w chwili regulowania płatności za dany towar lub usługę przez nabywcę. Nabywca, będący podatnikiem VAT, wystawia w takiej sytuacji jedno polecenie przelewu, a wpłacana przez niego kwota jest w ramach elektronicznej płatności dzielona na kwotę netto oraz kwotę podatku od towarów i usług. Ta część płatności, która zostanie zadeklarowana przez płacącego jako odpowiadająca wartości netto, pozostaje do swobodnej dyspozycji odbiorcy, ponieważ trafi na jego rachunek oszczędnościowo-rozliczeniowy. Natomiast ta część, która zostanie zadeklarowana jako kwota podatku od towarów i usług, zostanie przeniesiona przez bank na specjalne konto - rachunek VAT (Skwierczyńska, 2018).

Środki zgromadzone na wyodrębnionym rachunku VAT będą cały czas własnością podatnika, jednak obrót nimi zostanie w pewien sposób ograniczony. Środki te podatnik może przeznaczyć nie tylko na zapłatę zobowiązania w podatku VAT, ale również na zapłatę: podatku dochodowego od osób prawnych, podatku dochodowego od osób fizycznych, podatku akcyzowego, należności celnych oraz składek ZUS (Mechanizm podzielonej płatności, 2019).

\section{Mechanizm podzielonej płatności w polityce rachunkowości jednostek samorządu terytorialnego}

Przepisy ustawy o podatku od towarów i usług nie zawierają sposobu prowadzenia ewidencji na potrzeby tego podatku. Jednostki samorządu terytorialnego mogą stosować sposób ewidencji księgowej, zależny tylko od przyjętej w danej jednostce polityki rachunkowości.

Po wprowadzeniu mechanizmu podzielonej płatności zbudowanie właściwego schematu rozliczania i ewidencjonowania podatku od towarów i usług w księgach rachunkowych jednostek samorządu terytorialnego jest bardzo istotne. Jednostki samorządu terytorialnego podczas planowania systemu ewidencji VAT muszą bowiem uwzględniać uregulowania związane także z gromadzeniem dochodów i realizacją wydatków budżetowych.

Proces centralizacji rozliczeń VAT, a w związku z nim określone doświadczenia w tym zakresie w jednostkach samorządu terytorialnego, pokazują, że ewidencja księgowa centralnego rozliczenia VAT jest usytuowana najczęściej w księgach rachunkowych budżetu, ale stosuje się również prowadzenie centralnego rozliczenia VAT w księgach rachunkowych urzędów tych jednostek (Rup, 2017).

Ewidencja księgowa rozliczeń VAT powinna być prowadzona w każdej jednostce organizacyjnej oraz urzędzie jednostki na koncie 225 „Rozrachunki z budżetami”, w analogiczny sposób jak dla podmiotu będącego samodzielnym podatnikiem VAT. 
Jeżeli centralny ośrodek rozliczeń VAT prowadzony jest w urzędzie jednostki, wówczas należy uzupełnić tę funkcję dla konta 225 „Rozrachunki z budżetami” w zakładowych planach kont jednostek organizacyjnych. Ewidencja centralnego ośrodka rozliczeń VAT obejmuje dwa rodzaje rozrachunków z urzędem skarbowym oraz jednostkami organizacyjnymi i odpowiednim urzędem jednostki samorządu terytorialnego prowadzonych na odrębnych kontach księgi głównej budżetu (Rup, 2017).

Wdrożenie split payment wiąże się z wprowadzeniem zmian w polityce rachunkowości przede wszystkim urzędów gmin, miast, urzędów marszałkowskich i starostw. Zmiany te dotyczą zwłaszcza odzwierciedlenia w planie kont faktu utworzenia kont VAT oraz wpływu na nie i wypływu z nich środków pieniężnych, jak również przepływów środków pieniężnych między rachunkami VAT a innymi rachunkami mającymi charakter rachunków rozliczeniowych (Wieczorek, 2018, s. 367).

T. Krawczyk (2018, s. 458) proponuje, aby jednostki samorządu terytorialnego wprowadziły do swojego planu kont nowe konto syntetyczne wraz z objaśnieniami zgodnymi co do zasady w zakresie uznania i obciążenia tego konta, wynikającymi z ustawy z dnia 29 sierpnia 1997 r. Prawo bankowe, a które będą występowały w tych jednostkach. Jednostki te zdaniem autorki muszą podjąć decyzję, czy czekają na wprowadzenie zmian w Rozporządzeniu Ministra Rozwoju i Finansów z dnia 13 września 2017 r. w sprawie rachunkowości oraz planów kont dla budżetu państwa, budżetów jednostek samorządu terytorialnego, jednostek budżetowych, samorządowych zakładów budżetowych, państwowych funduszy celowych oraz państwowych jednostek budżetowych mających siedzibę poza granicami Rzeczypospolitej Polskiej, które powinny ująć konto rachunku VAT, czy też będą analitycznie rozbudowywać konto rozliczeniowe, o dodatkowe konto analityczne „Rachunek VAT”. Rachunek VAT powinien być powiązany z rachunkiem rozliczeniowym przeznaczonym dla wydatków bieżących, z racji tego, że odprowadzenie zobowiązania finansowego do fiskusa stanowi dla jednostki samorządu terytorialnego wydatek klasyfikowany w par. 453 i jest wykazywany w sprawozdaniu Rb-28S (Wieczorek, 2018, s. 367).

W objaśnianiach do konta „Rachunek VAT” należy zapisać, że konto w szczególności będzie służyło do ujmowania (Krawczyk, 2018, s. 458):

- operacji otrzymania płatności w części odpowiadającej kwocie VAT, dokonanej w mechanizmie podzielnej płatności,

- operacji dokonania zapłaty (części zapłaty obejmującej VAT) za nabyte towary i usługi,

- operacji otrzymania lub dokonania zapłat (całości lub części VAT) wynikających z faktur korygujących,

- spłat zobowiązań z tytułu VAT lub otrzymania zwrotu ewentualnych nadwyżek. Ujęcie w księgach rachunkowych zakupu towarów (usług) w jednostce stosującej mechanizm podzielonej płatności powinno być następujące (Bartosiewicz, 2018; Niemiec, 2018):

1) faktura dokumentująca zakup towarów (usług):

Wn konta zespołu 4 Koszty według rodzajów i ich rozliczenie - wartość netto, 
Wn konto 225 „Rozrachunki z budżetami” - VAT naliczony,

Ma konto 201 „Rozrachunki z odbiorcami i dostawcami” - wartość brutto;

2) zapłata za fakturę (zgodnie $\mathrm{z}$ komunikatem przelewu):

Wn konto 201 „Rozrachunki z odbiorcami i dostawcami” - wartość brutto,

Ma konto 130 „Rachunek bieżący jednostki” - wartość netto, Ma konto („Rachunek VAT") - VAT naliczony.

Natomiast ujęcie w księgach rachunkowych sprzedaży, np. usług w jednostce stosującej mechanizm podzielonej płatności, powinno być następujące (Bartosiewicz, 2018; Niemiec 2018):

1) faktura VAT dotycząca sprzedaży:

Wn konto 221 „Należności z tytułu dochodów budżetowych” - wartość brutto, Ma konto zespołu 7 - wartość netto,

Ma konto 225 ,Rozrachunki publicznoprawne” - VAT należny;

2) otrzymanie zapłaty za ww. fakturę:

Wn konto 130 „Rachunek bieżący jednostki” - wartość netto,

Wn konto „Rachunek VAT” - kwota VAT,

Ma konto 221 „Należności z tytułu dochodów budżetowych” - wartość brutto.

Ewidencję wpłaty podatku VAT (nadwyżki VAT należnego nad naliczonym) do urzędu skarbowego księguje się:

Wn konto 225 „Rozrachunki publicznoprawne”,

Ma konto „Rachunek VAT”.

W sytuacji, gdy na koniec roku zostaną środki na rachunku VAT, konieczne stanie się ich wykazanie w aktywach jednostki w środkach obrotowych, natomiast w pasywach należy wykazać zobowiązanie podatkowe, jeśli wynika z deklaracji VAT-7, oraz zobowiązania wobec dostawców i usługobiorców (Wieczorek, 2018, s. 368).

Jednostka samorządu terytorialnego, będąca scentralizowanym i zarejestrowanym czynnym podatnikiem VAT, może (ale nie musi) założyć w banku konto do podzielonej płatności wszystkim swoim jednostkom ${ }^{1}$. Może w związku z tym występować wariant $\mathrm{z}$ jednym rachunkiem VAT, tj. na poziomie ewidencji budżetu (organu jednostki), co jednak komplikuje rozliczenia z podległymi jednostkami, ponieważ całość środków ze realizowanych przez nie dochodów nie będzie mogła przepływać przez rachunki bankowe będące $w$ ich posiadaniu i takie rozwiązanie ze względu na zasady rozliczeń, m.in. jednostek budżetowych $\mathrm{z}$ budżetem, będzie sprzeczne z zasadami wykonania dochodów samorządów (Bartosiewicz, 2018). A. Bartosiewicz (2018) stwierdza, że wariant z wieloma rachunkami VAT byłby odpowiedni dla jednostek samorządu terytorialnego. Oznacza to, iż dla jednostki samorządu teryto-

${ }^{1}$ Jak zapisano w art. 62a ust. 3 ustawy Prawo bankowe: „Dla rachunków rozliczeniowych prowadzonych dla tego samego posiadacza bank prowadzi jeden rachunek VAT, niezależnie od liczby prowadzonych dla tego posiadacza rachunków rozliczeniowych. W przypadku prowadzenia więcej niż jednego rachunku rozliczeniowego dla tego samego posiadacza bank prowadzi, na wniosek tego posiadacza, więcej niż jeden rachunek VAT". 
rialnego jako jednego podatnika VAT, mającej w banku więcej niż jeden rachunek rozliczeniowy, na jej wniosek może zostać założony więcej niż jeden rachunek VAT.

Kwestią, którą należy podkreślić w omawianym problemie jest fakt, że stworzenie wielu kont VAT i wpisanie ich do polityki rachunkowości, to zabieg techniczny, natomiast zasadniczy problem pojawia się w możliwości dysponowania tymi środkami i zarządzania ich przepływem w taki sposób, aby jednostki samorządu terytorialnego w sposób efektywny wykorzystywały swoje zasoby w postaci środków pieniężnych i mogły bez przeszkód realizować zadania na nie nałożone.

Wariant z wieloma rachunkami VAT wydaje się najkorzystniejszym rozwiązaniem, jednakże należy zwrócić tutaj uwagę na kilka aspektów. Jednostka samorządu terytorialnego może założyć jeden rachunek VAT dla danej jednostki organizacyjnej, co daje możliwość swobodnego transferu środków na rachunku VAT w ramach rozliczeń wewnętrznych ze skarbnikiem jednostki samorządu terytorialnego. Jednak w sytuacji, gdy np. na rachunku VAT będą widniały środki pieniężne, a jednostka organizacyjna ma kilka rachunków bankowych rozliczeniowych, nie można powiązać rachunku bankowego VAT tylko z określonym rachunkiem bankowym, np. rachunkiem dochodów. Załóżmy, że na rachunku bankowym VAT jest saldo z transakcji handlowej dokonanej przez daną jednostkę organizacyjną oraz jednostka ta realizuje przelew w ramach mechanizmu podzielonej płatności za zakup usługi. Dokonując płatności w ramach mechanizmu podzielonej płatności, bank musi pobrać środki, które są na rachunku bankowym VAT. W takim razie rachunek bankowy VAT nie będzie powiązany tylko $\mathrm{z}$ rachunkiem dochodów.

Z kolei gdy jednostka założy oddzielne rachunki VAT dla wszystkich prowadzonych przez daną jednostkę organizacyjną rachunków rozliczeniowych, również - i to oczywiście duża zaleta - występuje możliwość swobodnego transferu środków na rachunku VAT w ramach rozliczeń wewnętrznych ze skarbnikiem jednostki samorządu terytorialnego. Jednak, podobnie jak wyżej, pojawia się problem praktyczny, gdy jednostka będzie posiadać na rachunkach VAT środki pieniężne. Załóżmy, że w tej sytuacji jednostka organizacyjna ma rachunek dochodów i rachunek bankowy VAT oraz rachunek wydatków i rachunek bankowy VAT. Na rachunku VAT z dochodów są określone środki za sprzedaż, na rachunku VAT z wydatków brak jest jakichkolwiek środków, a jednostka organizacyjna zamierza zapłacić za fakturę w ramach mechanizmu podzielonej płatności. Zatem czy bank, realizując przelew, zabierze środki z rachunku VAT wydzielonego do rachunku dochodów? Jak się okazuje w praktyce, jest z tym różnie. Zastanowić się zatem należy, czy mnożenie rachunków VAT i ich analiza, co na którym się znajduje, nie będzie się stawać zbyt kłopotliwa i czy nie wpłynie to na dysponowanie środkami na kontach VAT. Nadmierne mnożenie kont VAT prowadzi obecnie do posiadania przez jednostki samorządu terytorialnego znacznej liczby (od kilkudziesięciu do nawet kilku tysięcy) rachunków VAT. 


\section{Zakończenie}

Polityka rachunkowości jest podstawą prowadzenia ksiąg rachunkowych w jednostkach samorządu terytorialnego. Zawarte w niej zasady wspomagają organizacyjnie i merytorycznie czynności, które prowadzą do rzetelnego przygotowania sprawozdań finansowych i budżetowych. Rozwiązania zawarte w polityce służyć powinny przede wszystkim usprawnieniu systemu rachunkowego przez wyraźne rozwiązania odnoszące się do poszczególnych obszarów rachunkowości jednostek samorządu terytorialnego.

Podstawą prawidłowego przygotowania polityki rachunkowości jednostek samorządu terytorialnego jest analiza zdarzeń gospodarczych zachodzących w tych jednostkach $\mathrm{z}$ uwzględnieniem m.in. zmian regulacji prawnych, jak wprowadzony mechanizm podzielonej płatności $\mathrm{W}$ każdej jednostce samorządu terytorialnego powinny zostać opracowane procedury dotyczące zasad stosowania mechanizmu podzielonej płatności, które należy opisać w polityce rachunkowości, a jednostki samorządu terytorialnego muszą uwzględnić te zmiany, aktualizując plan kont. Zaznaczyć należy, że dodanie w planie kont nowych kont VAT nie jest zmianą, a tylko aktualizacją polityki rachunkowości, zatem może ona być dokonana w trakcie roku obrotowego.

W wyniku przeprowadzonych badań stwierdzono, że stworzenie konta VAT i wpisanie tego konta do polityki rachunkowości to zabieg tylko techniczny, natomiast zasadniczy problem pojawia się w możliwości dysponowania środkami na tym koncie i zarządzania ich przepływem w taki sposób, aby jednostki samorządu terytorialnego w sposób efektywny wykorzystywały swoje zasoby w postaci środków pieniężnych i mogły bez przeszkód realizować zadania na nie nałożone.

$\mathrm{Na}$ chwilę obecną wybór wariantu $\mathrm{z}$ wieloma rachunkami VAT jest rozwiązaniem lepszym od wariantu $\mathrm{z}$ jednym rachunkiem VAT na poziomie organu czy urzędu z punktu widzenia rozliczeń jednostki organizacyjnej z jednostką samorządu terytorialnego jako organem. Jednakże nie można się zgodzić do końca ze stwierdzeniem, że wariant ten usprawnia proces przepływu przez rachunki bankowe środków publicznych. Pomijając powstałe obecnie w niektórych jednostkach samorządu terytorialnego nadmierne liczby rachunków VAT, należy zauważyć, że w wariancie tym $\mathrm{w}$ jednostce organizacyjnej pojawia się problem powiązania rachunku VAT z określonym rachunkiem rozliczeniowym i ścisłej kontroli widniejących na nim środków w transakcjach kupna i sprzedaży dokonywanych przez jednostki organizacyjne jednostek samorządu terytorialnego. 


\section{Literatura}

Adamek-Hyska, D. (2018). Zakres polityki rachunkowości i odpowiedzialność za jej opracowanie. Finanse Publiczne, październik.

Bartosiewcz, A. (2018). Split payment a centralizacja rozliczeń VAT w gminach. Vademecum doradcy podatkowego, e-Biuletyn, (7).

Giedroyć, M. i Hellich, E. (2018). Wzorcowy plan kont w kontekście polityki rachunkowości. Aktualne zasady prowadzenia ewidencji księgowej dla jednostek sfery budżetowej. Warszawa: Infor.

Gos, W. i Hońko, S. (2011). Prezentacja zmian polityki rachunkowości w sprawozdaniach finansowych spółek objętych indeksem WIG 20. Zeszyty Teoretyczne Rachunkowości, 60(116), Warszawa.

Krawczyk, T. (2018). Mechanizm podzielnej płatności w jednostkach samorządu terytorialnego. W: M. Kaczurak-Kozak, M. Rotkiewicz i P. Walczak (red.), Vademecum głównego księgowego jednostki finansów publicznych. Warszawa: C. H. Beck.

Lander, G. P. (2003). What is Sarbanes - Oxley? New York: The Mc Graw-Hill.

Mechanizm podzielonej płatności. (2019). Objaśnienia podatkowe z 23 grudnia 2019 r. w sprawie mechanizmu podzielonej płatności. Pobrano z file://C:/Users/Agnieszka/Desktop/Objaśnienia_podatkowe_MPP.pdf

Niemiec, R. (2018). Ewidencja księgowa podzielonej płatności na rachunku VAT w urzędzie JST. System Informacji Prawnej LEX.

Prokop, D. (2018). Mechanizm podzielonej płatności. Split payment. W: D. Prokop, W. Kieszkowski, S. Majerowski i T. Wagner (red.), Mechanizm podzielonej płatności. Split payment. Tło, korzyści, zagrożenia. Ujęcie branżowe. Warszawa: Wolters Kluwer.

Rechul, H. i Witowska, J. (2014). Polityka rachunkowości w jednostkach sektora finansów publicznych. W: A. Kostur i J. Pfaff (red.), Polityka rachunkowości a kształtowanie wyniku finansowego. Zeszyty Naukowe Uniwersytetu Ekonomicznego w Katowicach. Katowice.

Rozporządzenie Ministra Rozwoju i Finansów z dnia 13 września 2017 r. w sprawie rachunkowości oraz planów kont dla budżetu państwa, budżetów jednostek samorządu terytorialnego, jednostek budżetowych, samorządowych zakładów budżetowych, państwowych funduszy celowych oraz państwowych jednostek budżetowych mających siedzibę poza granicami Rzeczypospolitej Polskiej (Dz. U. z 2017 r., poz. 911)

Rup, W. (2017). Jak księgować VAT w samorzadach przy centralizacji rozliczeń. Pobrano z https://www. rp.pl/Finanse/304059987-Jak-ksiegowac-VAT-w-samorzadach-przy-centralizacji-rozliczen.html

Sawicki, K. (1996). Polityka bilansowa i sprawozdawczość finansowa w zarzadzaniu firma. Wrocław: EKSPERT.

Skwierczyńska, E. (2018). Mechanizm podzielonej płatności VAT w sektorze publicznym. Finanse Publiczne, czerwiec.

Ustawa z dnia 11 marca 2004 r. o podatku od towarów i usług (tekst jedn. Dz. U. z 2020 r., poz. 106)

Ustawa z dnia 15 grudnia 2017 r. o zmianie ustawy o podatku od towarów i usług oraz niektórych innych ustaw (Dz. U. z 2018 r., poz. 62 ze zm.)

Ustawa z dnia 29 sierpnia 1997 r. Prawo bankowe (Dz. U. z 2019 r., poz. 2357 ze zm.)

Ustawa z dnia 29 września 1994 r. o rachunkowości (Dz. U. z 2019 r., poz. 351 ze zm.)

Walińska, E. (2016). Teoretyczne i praktyczne aspekty polityki rachunkowości. Finanse, Rynki Finansowe, Ubezpieczenia, 2(80), cz. 2.

Wieczorek, P. (2018). Obowiązki skarbnika w zakresie wdrożenia w urzędzie mechanizmu podzielnej płatności w VAT. W: P. Walczak (red.), Vademecum skarbnika jednostki samorząu terytorialnego. Warszawa: C. H. Beck.

Zuchewicz, J. (2011). Polityka rachunkowości jednostki oraz ujęcie jej zmian w sprawozdaniu finansowym według regulacji polskich i międzynarodowych. Zeszyty Teoretyczne Rachunkowości, 60(116), Warszawa. 


\title{
CHANGES IN THE ACCOUNTING POLICY OF LOCAL GOVERNMENT RESULTING FROM THE INTRODUCTION OF 'SPLIT PAYMENT' IN VALUE ADDED TAX
}

\begin{abstract}
The mechanism of 'split payment' was introduced specifically to counteract abuse of, and tax fraud. As a result of the introduction of new regulations, said regulations also pertain to local governmental units since they are VAT taxpayers. The purpose of the article is to present new institutions of public laws required in Poland's legal structures with the obligations of recording VAT by local authorities and consequences of the adoption by local government units of individual solutions in the maintenance of one or more VAT accounts. The applied research methods include the analysis of law statutes and literature review and inference.As a result of the conducted research, it was found that local government units being a centralized and registered active VAT taxpayer should go in the direction of using in their accounting policy a variant with multiple VAT accounts, which will improve the process of recording split payments in the body and organizational units.
\end{abstract}

Keywords: accounting policy, local government, split payment. 